Jusmal llmial

PEUR AA DE

Vol. 5, No. 2, May 2017

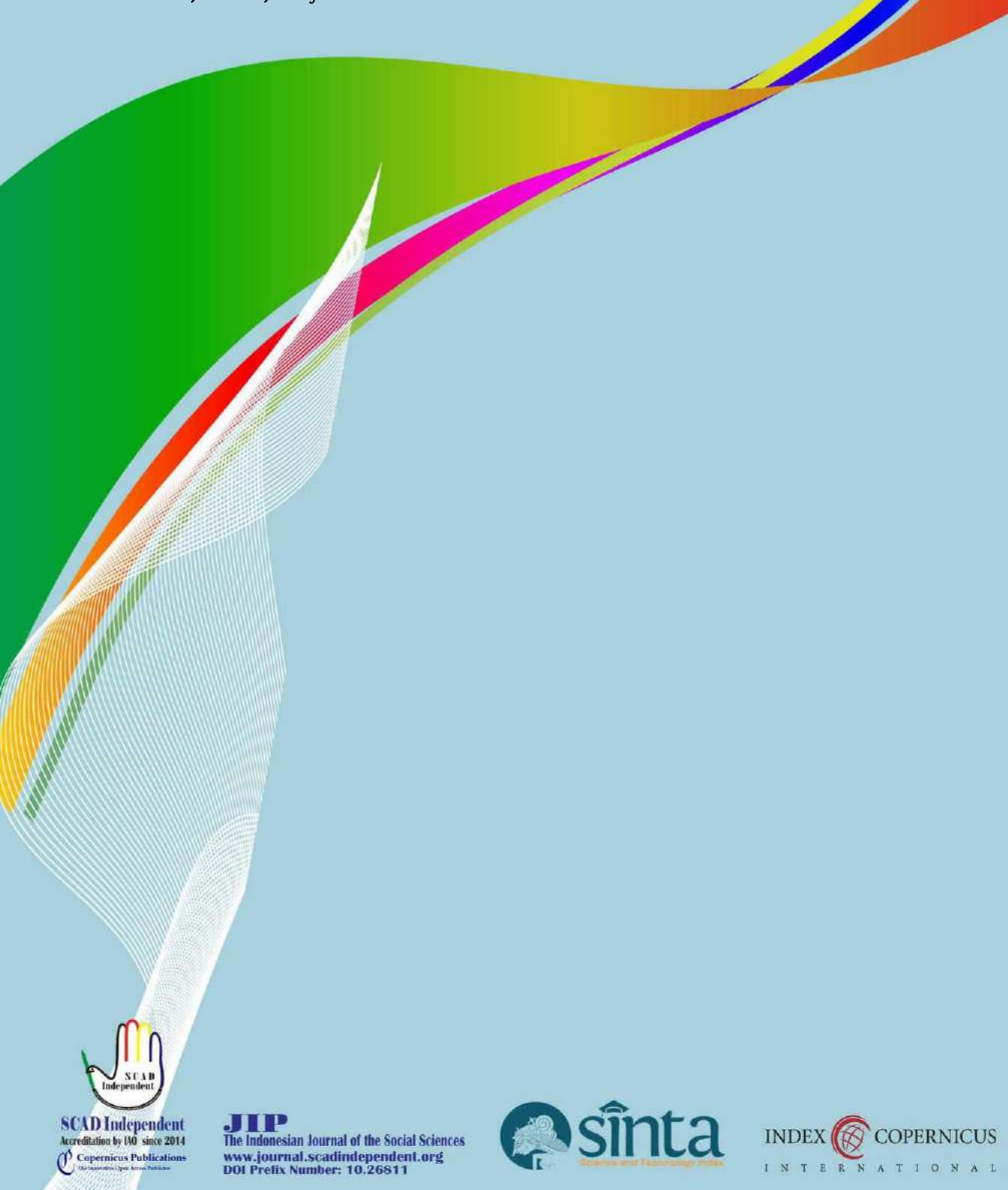




\title{
DIMENSIONS OF HOTEL SERVICE QUALITY IN MONGOLIA
}

\author{
Lkhamtseden. B ${ }^{1}$ \& Altanchimeg Zanabazar ${ }^{2}$ \\ 1,2Department of Management, Business School, National University of Mongolia, \\ Mongolia \\ 1Contibutor Email: lhamka_128@yahoo.com
}

Received: January 11, $2017 \quad$ Accepted: April 21, $2017 \quad$ Published: May 27, 2017

Article Url: http://journal.scadindependent.org/index.php/jipeuradeun/article/view/130

\begin{abstract}
Service quality has emerged as an important area in the hotel industry for decades. Thus, it is essential that service providers understand customer expectations and perceptions as well as the factors that influence their evaluation and satisfaction with the provided service. Hotel industry is growing each year in Mongolia. Realizing the increase in competition among hotels, hotel managers are focusing on improving the elements which contribute to service quality for customers of the hotel industry in Mongolia. The quality of service in hotel industry is an important factor of successful business. This study identifies the effects of various elements of hotel industry which affects customer satisfaction. Almost all researchers utilized service quality model and adopted their SERVQUAL instrument, based on the concept that service quality differs from industry to industry. Examining additional dimensions, identified by customers, it should be included in the service quality concept. Further, the level of importance of each specific dimension for the users of hotel services in Mongolia is then measured.
\end{abstract}

Keywords: Hotel, Service Quality, Customer Satisfaction, Monggolia 


\section{A. Introduction}

Hotel industry has become one of the substantial industries in global industries. Hotel industry has been a major growth in recent years in Mongolia. However it is not comparable with another countries growth. Realizing the increase in competition among hotels, are focusing on improving service quality to put them in a competitive advantage (Min and Min, 1996). In general, perceived service quality seems to be positively related to customer's likelihood of remaining a loyal customer and their attitudes toward the service provider (Anton et al., 2007; Bell et al., 2005; Aydin and Ozer, 2005).

According to Berry et al (1989), service quality of the hotel industry affects brand image, customer satisfaction and loyalty, and profit as well. One of the main reasons is that today's hotel guests are better traveled than previous generations and have clear notions of good service (Chacko, 1998).

Providing excellent service quality and high customer satisfaction is the most important issue and challenge facing the contemporary service industry (Hung et al., 2003). Kandampully et al., (2001) suggested that attempt to have effective service quality management is the best way to achieve superior customer satisfaction.

Oakland (2005) and Kandampully et al., (2001) showed that service quality can only be achieved if organizations empower their employees to underpin service quality dimensions. These dimensions include tangibles (physical facilities, equipment, and appearance of personnel); reliability (ability to perform the promised service dependably and accurately); responsiveness (willingness to help customers and provide prompt service); assurance (knowledge and courtesy of employees and their ability to convey trust and confidence); and empathy (caring, individualized attention provided to customers)., then the reasons must be developed based on the existing concrete data.

\section{B. Literature Review}

Service quality is considered the life of hotel (Min and Min, 1996) and core of service management (Chen, 2008) Service quality is related with 
customer satisfaction (Shi \&Su, 2007) and customer satisfaction is associated with customers revisit intention (Han et al., 2009). If an effective image is portrayed to customers, it will create competitive advantage for hotel (Ryu et al., 2008). Service quality was defined by Zeithaml (1988) as "the judgment of customers about the overall superiority of a product or service." Gronroos (1988) posited that perceived quality is considered good when the experienced quality of customers meets the expected quality from the brand. They defined service quality as "a global judgment or attitude relating to the overall excellence or superiority of the service".

Based on this definition, they operationalized the concept by applying Oliver's (1980) disconfirmation model of the gap between expectation and perception of service quality levels. Although SERVQUAL has been applied to a variety of service businesses, a number of dimensions and the nature of the construct were industry specific. Related researches showed that the dimensions were not replicable, and sometimes, the SERVQUAL scale was even unidimensional (Babakus and Boller, 1992) or ten-dimensional (Carman,1990).

These factors or dimensions are tangibles (physical facilities, equipment and appearance of personnel), reliability (ability to perform the promised service dependably), responsiveness (willingness to help and provide prompt service), assurance (knowledge and courtesy of employees and their ability to inspire trust and confidence), and empathy (caring, individualized attention the firm provides its customers).The most famous model of service quality was proposed by Parasuraman, et al., $(1985,1988)$. It had five dimensions and can be explained as:

1st - Reliability: "the degree to which a promised service is performed dependably and accurately".

2nd - Responsiveness: "the degree to which service providers are willing to help customers and provide prompt service".

3rd - Assurance: "the extent to which service providers are knowledge able, courteous, and able to inspire trust and confidence". 4th - Empathy: "the degree to which the customers are offered caring and individualized attention".

5th - Tangibles: "the degree to which physical facilities, equipment, and appearance of personnel are adequate. 
Mei et al.,(1999) studied service quality in the hotel industry in Australia, using SERVQUAL, and developed the HOLSERV scale. The results showed that "employees", "tangibles", and "reliability" were the three predictive dimensions of service quality, with "employees" as the best predictor. Another study conducted by Saleh and Ryan (1992) reported five dimensions of "conviviality", "tangibles", "reassurance", "avoid sarcasm" and "empathy", with "empathy" being the most important dimension of service quality. Sirra et al., (1999) designed a similar questionnaire of HOTELQUAL to examine customer's perceptions of hotels and delineated three factors of "hotel facilities", "appraisal of the staff", and "functioning and organization of service".

Recently, Ekinci et al., (2003) found that tangible and intangible dimensions are the only two distinct dimensions measuring service quality of hotels. Lastly, Akbaba (2006) investigated the service quality expectations of business hotel's customers and identified five service quality dimensions, namely tangibles, adequacy in service quality, understanding and caring, assurance, and convenience.

In hotel industry, as service has direct interaction with customers, that is why customer satisfaction can be are placation of service quality in hotels (Shi and Su, 2007). Hotel performance is directly allied to service quality improvement. There is a significant relationship exist between improvement in service quality and hotel performance change (Narangajavana and $\mathrm{Hu}$, 2008). Customers revisit intention and emotions are mediated by customer satisfaction (Han et al., 2009).

Customer satisfaction plays a role of mediator in perceived value of hotel and behavioral intention (Ryu et al., 2008). Customers revisit intention and emotions are mediated by customer satisfaction (Han, Back and Barrett, 2009). Customer satisfaction plays a role of mediator in perceived value of hotel and behavioral intention (Ryu,Han and Kim, 2008).

In every organization service and quality plays a vital role for every customer (Brombacher, 2000). Customer is the main person who defines the Quality (Berry and Parasuraman; Zeithaml and Adsit; Hater and Vanetti, Veale; 1993). For providing good quality service to customers, it is necessary 
for hotel managers to understand the expectations of its customers (Shi and $\mathrm{Su}, 2007$; Nilssom and Gustafsson, 2001) and then develop such programs that can address issues of customers (Narangajavana and Hu, 2008) and bring improvement in service quality (Chen, 2008).

Customer is the main person who defines the Quality (Berry and Parasuraman; Zeithaml and Adsit; Hater and Vanetti;Veale, 1993). For providing good quality service to customers, it is necessary for hotel managers to understand the expectations of its customers (Shi and $\mathrm{Su}, 2007$; Nilssom and Gustafsson, 2001) and then develop such programs that can address issues of customers (Narangajavana and $\mathrm{Hu}, 2008$ ) and bring improvement in service quality (Chen, 2008).

Customers demand and expectations continue to change according to market that is why hotel managers must timely know those expectations and improve their service quality accordingly (Chen, 2008). Besides this, different customers have different perception of service quality, so there is a need to cater this problem also (Shi and $\mathrm{Su}, 2007$ ).

When service quality is improved, then it will lead to customer satisfaction that will result in good business results (Johnson and Gustafsson, 2001). It is necessary to scrutinize the perceptions of hotel managers about hotel ranking and they should correlate it with improving service quality and performance (Narangajavana and $\mathrm{Hu}, 2008$ ). To bring improvement in service quality, there is a need to emphasis on tangible and intangible assets (Narangajavana and $\mathrm{Hu}, 2008$ ).

\section{The Link between Service Quality and Customer Satisfaction}

Gabbie and O'Neill (1996) observed that in today's hospitality environment, the true measure of company success lies inan organization's ability to satisfy customers continually. There has been some confusion regarding the differences between service quality and satisfaction (Storbacka et al., (1994). Satisfaction would, according to Liljander and Strandvik (1994), refer to an insider perspective, the customer's own experiences of a service where the outcome has been evaluated in terms of what value was received, in other words what the customer had to give to get something. According to 
Hunt (1977), satisfaction is an evaluation that an "experience was at least as good as it was perceived to be".

\section{Measurement of service quality}

Parasuraman et al., (1988) defined service quality as "a global judgment or attitude relating to the overall excellence or superiority of the service" and they conceptualized a customer's evaluation of overall service quality by applying Oliver's(1980) disconfirmation model, as the gap between expectations and perception of service performance levels.

Further more, they propose that overall service quality performance could be determined by the measurement scale SERVQUAL that uses five generic dimensions: tangibles (the appearance of physical facilities, equipment, personnel, and communications materials); reliability (the ability to perform the promised service dependably and accurately); responsiveness (the willingness to help customers and provide prompt service); assurance (the competence of the system and its credibility in providing a courteous and secure service); and empathy (the approach ability, ease of access and effort taken to understand customers' needs).

\section{Research Aim}

The objective of this study is to measure and evaluate the service quality in corporate hotels it is important for hoteliers and marketers to be able to define the importance of service quality dimensions (tangibility, reliability, responsiveness, assurance, and empathy) and their relative importance to guests' satisfaction. Having knowledge about guests' expectations, will help hotel managers know what to improve upon and whether service quality has been met with service providers or exceeded in their hotels. This would provide the basis expectations and actual performance to assist managers in reducing the gap felt by guests between expectations and the actual service provided. Although it is generally accepted that effective service management has a positive impact on customer satisfaction, the research still aims to gain more insight into these areas. 


\section{Research Finding and Discussion}

\section{Research Hypotheses}

In order to answer the above questions literature has been extensively reviewed to devise the following hypotheses:

H.1: There is no significant difference between service quality dimensions and customers satisfaction.

H1.1: There is no significant difference between empathy and customers' satisfaction.

H1.2: There is no significant difference between reliability and customers' satisfaction.

H1.3: There is no significant difference between Assurance and customers' satisfaction

H1.4: There is no significant difference between responsiveness and customers' satisfaction

H1.5: There is no significant difference between tangibles and customers' satisfaction

\section{Research methodology}

In this research paper, we examined aspects of service quality that affect customer satisfaction and results in success of hotels. The current research uses a questionnaire as a tool to collect data from the sample group whom are international tourists who were visiting Corporate and staying at hotels tourists during the time the survey was conducted. The samples for this survey were selected regardless of their nationality, age and gender, and included all types from those wanting luxury to backpackers, etc.

In the questionnaire the questions were adopted from previous research. It measures service quality by implementing the five dimensions of the "SERVQUAL" instrument: each dimensions followed by four questions. The 5-point Likert -scale is used for all responses with ( $1=$ strongly disagree, $2=$ disagree, $3=$ neither agree nor disagree, $4=$ agree, $5=$ strongly agree).

\section{Research Framework}

In the questionnaire, the questions are divided into two sections (Dependent variable and the Independent variable).This research targeted 203 respondents. 
However, only 190 (95.9\%) questionnaires were returned. Since the respondents did not properly complete the, questionnaires. Those questions were adopted from previous research. It measures service quality by implementing the five dimensions of the "SERVQUAL" the each dimensions followed by four questions 5-point Likert-scale is used for all responses with labels ( $1=$ strongly disagree, 2 = disagree, $3=$ neither agree nor disagree, $4=$ agree, $5=$ strongly agree).

Group 1: The items for measuring empathy are questions(1-4)

Group 2: The items for measuring reliability are questions (5-8)

Group 3: Items for measuring assurance are questions (9-12)

Group 4: Items for measuring responsiveness are questions (13-16)

Group5: Items for measuring tangibles are questions (17-20)

Group 6: Items for measuring customer satisfaction is question 21.

\section{Statistical Analysis}

In order to analyze the questionnaire data, statistical analysis was done using the SPSS software.

Statistical Inferences used are as follows:

- Reliability Analysis, used to measure reliability using Cronbach alpha.

- Chi-Square Testing, used to test if there is a difference between two variables.

- Regression analysis, used to assess how much do each independent affect Customer Satisfaction (dependent variable). It also gives an indication of the relative contribution of each independent variable.

Table 1: Questionnaire Summary

\begin{tabular}{|c|l|}
\hline Dimension & \multicolumn{1}{c|}{ Questionnaire Items } \\
\hline \multirow{3}{*}{ Empathy } & Friendliness and courtesy of staffs \\
& $\begin{array}{l}\text { Providing a menu for diet } \\
\text { Understands specific needs of guests } \\
\text { Special attention given by staff to know each guest }\end{array}$ \\
\hline Reliability & $\begin{array}{l}\text { Well-trained and knowledgeable staff } \\
\text { Handled complaints and problems graciously }\end{array}$ \\
\hline
\end{tabular}


Lkhamtseden. B E Altanchimeg. Z

\begin{tabular}{|c|l|}
\hline & $\begin{array}{l}\text { Provides services as promised } \\
\text { Performs services right at the first time }\end{array}$ \\
\hline \multirow{3}{*}{ Assurance } & $\begin{array}{l}\text { Instilling confidence in guests } \\
\text { Convenience of service availability } \\
\text { Occupational knowledge of employees } \\
\text { Provides a safe and secure place for guests }\end{array}$ \\
\hline \multirow{2}{*}{ Responsiveness } & $\begin{array}{l}\text { Gives individual attention to guests } \\
\text { Provides prompt services } \\
\text { Willingness of staffs to help guests } \\
\text { Availability of employees when needed }\end{array}$ \\
\hline Customer & $\begin{array}{l}\text { Attractiveness of the hotel decorate and design } \\
\text { Attractiveness of the hotel decorate and design } \\
\text { Neat and professional appearance of staffs } \\
\text { Modern-looking and well-maintain hotel equipments } \\
\text { Quietness of the hotel environment for purpose of stay }\end{array}$ \\
\hline Oatisfaction & Overall, I am satisfied with the hotel services \\
\hline
\end{tabular}

- Stepwise Regression analysis, used to assess the most effective independent variables which affect Customer Satisfaction (dependent variable).

\section{a. Reliability Analysis}

Reliability test is an assessment of the degree of consistency between multiple measurements of a variable. Cronbach's alpha is the most widely used measurement tool with a generally agreed lower limit of 0.6.The following Table provides an overview of the reliability scores. As can be seen from this table, all the alpha coefficients were above the required level of 0.6 .

\section{Table 2: Reliability}

\begin{tabular}{|c|c|c|}
\hline Variable & Number of items & Cronbarch's Alpha \\
\hline Empathy & 3 & .634 \\
\hline Reliability & 4 & .743 \\
\hline Assurance & 4 & .607 \\
\hline Responsiveness & 4 & .647 \\
\hline Tangibles & 3 & .804 \\
\hline
\end{tabular}




\section{b. Testing Hypotheses using Chi-Squared Test}

H1.1: There is no significant difference between Empathy and Customer Satisfaction. Testing this using the relevant questions, Chisquare $=37.586(\mathrm{DF}=8$, sig. $=0.000)$. This shows a significant relation between Empathy and Customer Satisfaction. This would enable the authors to reject the null hypothesis.

H1.2: There is no significant difference between Reliability and Customer Satisfaction. Testing this using the relevant questions, Chisquare $=68.773(\mathrm{DF}=12$, sig. $=0.000)$. This shows a significant relation between Reliability and Customer Satisfaction. This would enable the authors to reject the null hypothesis.

H1.3: There is no significant difference between Assurance and Customer Satisfaction. Testing this using the relevant questions, Chisquare $=48.262(\mathrm{DF}=12$, sig. $=0.000)$. This shows a significant relation between Assurance and Customer Satisfaction. This would enable the authors to reject the null hypothesis.

H1.4: There is no significant difference between Responsiveness and Customer Satisfaction. Testing this using the relevant questions, Chisquare $=56.978(\mathrm{DF}=8$, sig. $=0.000)$. This shows a significant relation between Responsiveness and Customer Satisfaction. This would enable the authors to reject the null hypothesis.

H1.5: There is no significant difference between Tangibles and Customer Satisfaction. Testing this using the relevant questions, Chisquare $=39.375(\mathrm{DF}=12$, sig. $=0.000)$. This shows a significant relation between Tangibles and Customer Satisfaction. This would enable the authors to reject the null hypothesis.

\section{Regression Analysis}

Regression analysis shows how much assessment do each independent variable affect Customer Satisfaction (dependent variable). By using this regression analysis, one may assess the direct relationship between variables as well as show the causal relationship and the nature of relationship between variables (Aiken et al., 1991; Foster et al., 2004). 
The stepwise regression model is defined as the step-by-step iterative construction of a regression model that involves automatic selection of independent variables. Stepwise regression can be achieved either by trying out one independent variable at a time and including it in the regression model if it is statistically significant, or by including all potential independent variables in the model and eliminating those that are not statistically significant, or by a combination of both methods. (Aiken et al., 1991; Berensonand Levine, 1992).

The SPSS stepwise regression procedure was employed in the table below to as certain the proposed relationships between the independent variables and the dependent variable.

\section{Table 3: Regression Analysis}

\begin{tabular}{|c|c|c|c|c|c|}
\hline \multicolumn{6}{|c|}{ Unstandardized Coefficients Standardized Coefficients } \\
\hline Model & B & Std. Error & Beta & $\mathrm{t}$ & Sig. \\
\hline (Constant) & .169 & .556 & & .304 & .762 \\
\hline Reliability & .344 & .106 & .254 & 3.235 & .002 \\
\hline Responsiveness & .397 & .119 & .254 & 3.329 & .001 \\
\hline Tangibles & .204 & .088 & .181 & 2.330 & .021 \\
\hline
\end{tabular}

Regression Analysis is shown in equation:

Estimated $Y=a+b 1 x+b 2 x+\ldots$.

Where $Y$ is the dependent variable, a is the $Y$ intercept, that is the value of $Y$ when $x=0, b 1, b 2, \ldots$ is the regression coefficients which indicate the amount of change in $Y$ given a unit change in $x 1, x 2, \ldots .$. , and $x 1, x 2, \ldots .$. are the values for the independent variables.

Based on the stepwise regression shown in the above table, the results are as follows:

Estimated $Y=0.169+0.344^{*}$ Reliability $+0.397^{*}$ Responsiveness + $0.204^{*}$ Tangibles.

Where:

Constant $\mathrm{a}=0.169$

Reliability Coefficient $=0.344$ 
Responsiveness Coefficient $=0.397$

Tangibles Coefficient $=0.204$

This means that in the presence of all variables together, only Reliability, Responsiveness and Tangibles variables show a significant impact on Customer Satisfaction in hotels, while both Empathy and Assurance variables impact become insignificant.

The highest impact is shown to be for Responsiveness (Coefficient $=0.397$ ), then comes Reliability variable (Coefficient $=0.344)$, while the least variable in its impact was Tangibles (Coefficient $=0.204$ )

The above results illustrate the impact of the responsiveness on the Customer satisfaction, where an increase in responsiveness by 0.397 will cause an increase in the customer satisfaction in hotel. Similarly, the reliability in hotel in Mongolia is directly affected by the customer satisfaction where an increase in reliability 0.344 will cause a direct increase in the customer satisfaction in hotels. Also, the customer satisfaction in hotel in Mongolia will be affected by Tangibles where an increase in Tangibles 0.204 will cause a direct increase in the customer satisfaction within hotels.

\section{E. Conclusion}

This study examined the aspects of service quality in hotels that influence the satisfaction of customers. The findings of this study suggested that impact of service quality affects the customer satisfaction that results in success of hotel and it is an irrefutable fact. Furthermore, sustaining the customer satisfaction level is an ongoing process that requires continuous improvement in service quality at hotels.

Based on study findings, it can be concluded that customers' perceptions regarding hotel brand quality dimensions such as "responsiveness", "reliability" and "empathy" contributed to build their satisfaction rather than "empathy" and "assurance". Interestingly, favorable perceptions on hotel responsiveness predicted relatively stronger satisfaction than did reliability and empathy perceptions. 
It is therefore essential for managers in hotel industry to apply the SERVQUAL model for the measurement of service quality, in order to satisfy the guest's expectations.

Limitations and avenues for future research.

This research has certain limitations, and interpretation of its findings therefore needs to be undertaken with caution. First, the sample in this study is small and is limited to a relatively specific group of tourists - citizens who stayed in certain hotels in Corporate.

\section{Bibliography}

Akbaba. A. (2006). Measuring service quality in the hotel industry: a study in a business hotel in Turkey" Hospitality Management, 25(2): 170-192. "Law on civil rights of foreign citizen", "State information" 1995 №2

Altanchimeg, Z., Battuya, D., \& Tungalag, J. (2016). The Current Circumstances and Challenges of Migrant Labor Force of Mongolia in North Eastern Asia. Jurnal Ilmiah Peuradeun, 4(1), 27-38.

Anton C, Camarer C, Carrero M. (2007). Analysing firms' failures as determinants of consumer switching intentions: The effect of moderating factors" European J. Marketing. 41(1/2): 135 -158. "Constitution of Mongolia", "State information"1992 №1

Asubonteng P, Mc Cleary KJ, Swan JE. (1996). SERVQUAL revisited: a critical review of service quality" The J. Service Marketing. 10(6):62-81.

Babakus MN, Boller GW. (1992). An empirical assessment of the SERVQUAL scale J. Bus. Res. 24(3): 253-268.

Berry LL, Bennet DR, Brown CW. (1989). Service Quality: A Profit Strategy for Financial Institutions. Homewood, IL: Dow-Jones-Irwin.

Chen JV, Aritejo BA. (2008). Service quality and customer satisfaction measurement of mobile value-added services: A conceptual review. 6:165-176 
Ekinci Y, Prokopaki P, Cobanoglu C. (2003). Service quality in Cretan accommodations: marketing strategies for the UK holiday market" Int. J. Hospitality Management. 22(1):47-66.

Gabbie O, O'Neill MA. (1996). SERVQUAL and the Northern Ireland hotel sector: A comparative analysis - Part 1" Managing Service Quality. 6(6): 25-32.

Gro"nroos C. (1990). Service management and marketing: managing the moments of truth in service competition. Lexington, MA: Lexington Books.

Hakim, L., \& Muis, A. (2016). Alternative Control of Insect Pests in Vegetable Plants Using Local Wisdom Approach. Jurnal Ilmiah Peuradeun, 4(1), 53-64.

Han H, Back K, Barrett B. (2009). Influencing factors on restaurant customers' revisit intention: The role of emotions and switching barriers". International J. Hospitality Management. 28(4): 563-572.

Herlina, H., \& Hamzah, A. (2015). Domestic Tourists' Response to Tourist Attractions in Sabang And Banda Aceh, Indonesia. Jurnal Ilmiah Peuradeun, 3(3), 371-380.

Hokey Min, Hyesung Min. (1996). Benchmarking the quality of hotel services: managerial perspectives" Int. J. Quality and Reliability Management. 14 (6): 582-597.

Hughes, K. J., \& Batten, L. (2016). The Development of Social and Moral Responsibility in Terms of Respect for the Rights of Others. Jurnal Ilmiah Peuradeun, 4(2), 147-160.

Hung Huang Chen. (2003).Service quality evaluation by service quality performance matrix. Total Quality Management and Business Excellence. 14(1): 79 .

Johnson MD, Gustafsson A. (2001). Improving customer satisfaction, loyalty and profit: an integrated measurement and management system. San Francisco, CA: Jossey-Bass

Kandampully J, C Mok, Sparks B. (2001). Service quality management in hospitality, tourism and leisure. Binghamton: Haworth.

Karatepe O M, Avci T. (2002). Measuring service quality in the hotel industry: evidence from Northern Cyprus", Anatolia: An Int. J. Tourism and Hospitality Res. 13(1):19-32. 
Mei AWO, Dean AM, White CJ. (1999). Analyzing service quality in the hospitality industry" Managing Service Quality. 9(2):136-143

Narangajavana Y, Hu B. (2008). The relationship between the hotel rating system, service quality improvement, and hotel performance changes: A canonical analysis of hotels in Thailand" J. Quality Assurance in Hospitality and Tourism. 9(1):34-56.

Oliver RL. (1980). A cognitive model of the antecedents and consequences of satisfaction decisions" J. Marketing Res. 17(4): 460-469.

Parasuraman A, Zeithaml VA, Berry LL. (1988). SERVQUAL: a multi-item scale for measuring consumer perceptions of service quality. J.Retailing. 64:12-40.

Ryu K, Han H, Kim T. (2008). The relationships among overall quick-casual restaurant image, perceived value, customer satisfaction, and behavioral intentions" Int. J. Hospitality Management. 27(3):459-469.

Saleh F, Ryan C. (1992). Analyzing service quality in the hospitality industry using the SERVQUAL model" The Service Industries J. 11(3):324-343.

Shi JH, Su Q. (2007). Evaluation of hotel service quality based on customer satisfaction, Service Systems and Service Management. 9 (11): 1-5.

Storbacka K, Strandvik T, Gronroos C. (1994). Managing Customer Relationships for Profit: The Dynamics of Relationship Quality" Int. J. Service Industry Management. 5(5): 21-38.

Valia T, Petkova Peter C, Sander Aarnout C, Brombacher. (2000). The use of quality metrics in service centres, Int. J. Production Econ. 6 7: 27-36. 
p-ISSN: 2338-8617

Vol. 5, No. 2, May 2017 e-ISSN: 2443-2067 